\title{
Vseživljenjsko učenje v visokem šolstvu - grožnja alì izziv?
}

$\checkmark$ Evropski uniji se na različnih ravneh poudarja pomen vseživljenjskega učenja kot ključne sestavine "družbe znanja". Tudi večina evropskih vlad namenja vseživljenjskemu učenju vidno vlogo v svojih političnih dokumentih in retorikah. Vlade morda bolj kot kadarkoli prej pričakujejo, da bodo univerze kot centri ustvarjanja in prenašanja znanja igrale pomembno vlogo $v$ ponudbi in izvedbi različnih vrst vseživljenjskega učenja. Tako so za visoko šlstvo odgovorni evropski ministri septembra 2003 podpisali uradno sporočilo "Uresničevanje evropskega visokošolskega prostora", v katerem med ostalimi cilji poudarjajo pomemben prispevek visokega šolstva pri uresničevanju vseživljenjskega učenja. Visokošolske institucije naj bi povečale možnosti vseživiljenjskega učenja na visokošolski ravni, vključno s priznavanjem prejšnjega, udi neformalnega učenja. Ministri se strinjajo, da je pomemben pogoj za izvedbo vseživljenjskega učenja razvoj skladnega kreditnega sistema, ki bi omogočal ovrednotenje in priznavanje diplom in spričeval, pridobljenih $v$ solah in na univerzah, ter priznavanje znanja, pridobljenega iz izkušenj na delovnem mestu. Na ta način bi bil zagotovljen prenos kvalifikacij med šlami, univerzami in svetom dela. Nadaljnje izobraževanje in usposabljanje predstavlja odgovor na naraščjočo tekmovalnost in uporabo novih tehnologij in zato postaja eden od najpomembnejših pristopov za doseganje strateških ciljev EU. Ta naj bi postala najbolj konkurenčna in dinamična, na znanju temelječa družba. Ministri pozivajo vse odgovorne za uresničevanje evropskega visokošolskega prostora, da vključijo širok razpon prožnih poti, možnosti in tehnik učenja ter ustrezno uporabo evropskega sistema prenosa kreditov (ECTS). Prav tako poudarjajo mujnost povečanja možnosti vseživljenjskih poti v okviru visokega šolstva za use državljanke in državljane, v skladu $z$ njihovimi željami, pričakovanji in sposobnostmi.

$V$ visokem šolstvu, zlasti na tradicionalnih univerzah, takšen koncept vseživljenjskega učenja ne sprejemajo z navdušenjem. Mnogi predstavniki akademskega sveta opozarjajo, da je vseživljenjsko učenje, kot ga opredeljujejo politiki, zmuzljiv koncept; njegove meje so spremenljive, njegovo področje delovanja je izredno šroko in posledice takšnega koncepta so za univerze nejasne. Prav tako opozarjajo, da je vseživljenjsko učenje kol koncept v nevarnosti, da postane retorična fraza: vse stvari za vse ljudi. Nedoslednosti takšnega koncepta izhajajo iz pričakovanj, ko naj bi vseživljenjsko učenje služilo protislovnim ciljem: predstavljalo naj bi sredstvo za povečanje demokratizacije, enakosti možnosti in družbene kohezije, hkrati pa naj bi pomenilo tudi način izpopolnjevanja razvoja človeških virov (kar je v EU terminologiji označeno z "zaposljivostjo") kot odgovor na zahteve globalizacije in gospodarske konkurenčnosti. Ta dvojnost ciljev istočasnega spodbujanja enakosti in večanja konkurenčnosti je v nasprotju $s$ tradicionalnim pojmovanjem univerzitetnega izobraževanja, ki je namenjeno nesebičnemu odkrivanju in širjenju znanja in resnice. Hkrati je vprašljivo, ali je mogoče takšna cilja uresničiti istočasno in v okviru iste institucije, ne da bi drug drugega kompromitirala. 
$V$ strokovni literaturi lahko zasledimo različne interpretacije pojma vseživljenjskega učenja, npr. liberalno, neoliberalno, postmoderno ali neosocialistično interpretacijo, Liberalna perspektiva pojmuje vseživljenjsko učenje kot razširjanje liberalnega izobraževanja, ki naj bi omogočalo izobraževanje za osebni razvoj čim večjega stevila ljudi v družbi. Glavna skrb neoliberalne perspektive je osredotočena na usposabljanje in pridobivanje spretnosti, ki naj bi služile tako osebnim materialnim koristim kot tudi ustvarjanju bolj konkurenčnega tržnega gospodarstva. $V$ postmoderni perspektivi je vseživljenjsko učenje osrednja sestavina novega pluralističnega, tolerantnega, igrivega in svobodomiselnega okolja, v katerem odprto polje učenja označuje družbo znanja. Iz neosocialistične ali egalitarne perspektive pa je vseživljenjsko učenje povezano z radikalnimi družbenimi nameni izobraževanja odraslih, s posebnim poudarkom na družbeni vključenosti, pridobivanju moči in demokratizaciji.

Cilji in nameni izobraževanja v kontekstu vseživljenjskega učenja so torej mnogovrstni; razvoj posameznika, socialna kohezija in gospodarska rast, povezana s tržnimi cilji. Tudi koncept znanja v okviru vseživljenjskega učenja vključuje vsaj dva različna vrednostna ideala: demokratični koncept znanja, ki veča socialno vključenost, kohezijo in sodelovanje, ter ekonomski koncept znanja, ki služi pridobivanju dohodka, ustvarjanju blaginje in globalne konkurenčnosti. Ključne značilnosti pojma vseživljenjskega učenja pa so naslednje: poudarek je tako na intrinzični kot tudi na instrumentalni pomembnosti izobraževanja in učenja; univerzalen dostop do možnosti izobraževanja; priznavanje učenja $v$ različnih okoljih in ne le v okviru izobraževalnih institucij; učenje skozi use življenje; pestrost metod poučevanja in načinov učenja, ki se razlikujejo od konvencionalnega izobraževanja; premik od poudarjanja učne snovi $k$ procesom učenja in premik od poučevanja $k$ učenju ter od preskrbe $k$ povpraševanju po izobraževalni ponudbi.
Koncept vseživljenjskega učenja (in z njim povezane politike) ima številne posledice tako za strukturo visokošolskih institucij kot tudi za organizacijo znanja. Ustvarjanje večjih možnosti učenja za nove in različne kategorije študentov pomeni, da študenti študija ne bodo začeli s pridobivanjem podobne vrste in obsega znanja. Namesto tega bodo pridobivali znanje iz različnih virov (npr: delovne izkušnje) in z različnih področij znanja. Ideja o tem, da so študenti oproščeni določenih delov stopenjskega programa, tako da se jim prizna njihovo učenje izven visokosolskega sistema, predstavlja premik v smeri različnega in do določene mere zunaj visokega solstva opredeljenega kurikuluma.

Priznavanje in potrjevanje izkustvenega učenja in učenja, ki izhaja iz dela, ogroža legitimnost organizacïje znanja na univerzah, saj nadomešca regulativna pooblastila akademskih disciplin in akademske skupnosti z večdisciplinarnimi, dina. mičnimi in bolj začasnimi oblikami pridobivanja znanja. Ta premik se še bolj krepi z zahtevo, naj univerze razvijejo ponudbo vseživljenjskega učenja, ki izhaja iz povpraševanja, kar je v nasprotju z dosedanjimi oblikami nadaljnjega izobraževanja, ki zagotavljajo določeno zalogo vnaprej ponujenih programov. Gre torej za sirjenje dostopa in spreminjanje ponudbe, ki naj bi bila bolj prilagojena široki paleti potreb posameznikov, svetu dela, skupnosti in družbi nasploh. Tako bodo verjetno glavne funkcije kurikuluma osredotočene na prenašanje in osva. janje splošno uporabnih in prenosljivih spretnosti.

Premik od znanja $k$ spretnostim je podoben premiku od vsebine k procesu. To vključuje bolj akcijsko usmerjen koncept znanja, v katerem so $v$ ospredju zlasti vprašanja "naučiti se učiti" razumevanje procesov učenja posameznika in ugotavljanje vrzeli in napredka v znanju. Vse kaže, da je razvoj spretnosti za učenje reakcija na naraščajočo zastarelost veljavnega znanja in zato 
naj bi bila to ena od ključnih potez znanja $v$ informacijski družbi.

Ta premik od osredotočenosti v zianje $k$ večjemu poudarku na spretnostih bo vplival na oblikovanje novih vlog učiteljev in študentov. Učiteljevo strokovno znanje ne bo več oprto le na specialistično znanje, $k i$ izhaja predvsem iz disciplinarno zasnovanega študija in raziskovanja, temveč tudi na razumevanje procesov učenja in sposobnosti prenašanja znanja na vrsto različnih problemov zunaj akademskega sveta. Učitelji bodo use bolj "spodbujevalci", ki pomagajo studentom, da postanejo "reflektivni praktiki". Pojmovanje "izobraženosti" bo vključevalo različne oblike delovanja (problemsko reševanje, odločanje itd.), opuščeno pa bo tudi tradicionalno razlikovanje med teorijo in prakso, znanjem in spretnostmi.

To so samo nekatere od možnih posledic uveljavljanja vseživljenjskega učenja v visokem solstvu in z njim povezanimi novimi koncepti. Če postaja znanje bistveno bolj socialno in bolj neposredno povezano z ekonomsko produkcijo, se zastavlja vprašanje, kaj lahko oziroma kaj morajo storiti univerze, da si zagotovijo svoje institucionalno in funkcionalno preživetje.

Mednarodna primerjalna raziskava o implikacijah vseživljenjskega izobraževanja na univerzah $\checkmark$ EU je pokazala zelo jasen trend v politiki in praksi vseživljenjskega učenja. Ne glede na različen obseg integriranosti in sprejetosti tradicionalnih predstav o nadaljnjem (profesionalnem) izobraževanju v okviru univerzitetnega izobraževanja so se univerze na nove izzive, povezane z vseživljenjskim učenjem, odzvale na dva značilna načina. Po eni strani so se zavedale, da bi bila zavrnitev ideje vseživljenjskega učenja "politično nekorektna" in so jo zato sprejele na politični ravni. Implementacijo novega koncepta, povezanega z idejo vseživljenjskega učenja, so najpogosteje izpolnile na retorični ravni in enostavno zamenjale izraz "nadaljnje izobraŽevanje" z "vseživljenjskim učenjem", ne da bi izvedle kakršnokoli spremembo v praksi in ponudbi. Do zanimivih ugotovitev je prišla tudi posebna delovna skupina, ki je na Univerzi v Ljubljani spremljala uresničevanje Bolonjskega procesa. Rezultati ankete so pokazali, da so anketirani na večini članic ljubljanske univerze relativno dobro seznanjeni z večino ciljev Bolonjske deklaracije, izjema je le cilj vseživljenjskega učenja, glede katerega prevladuje mnenje, da gre predvsem za organizacijo izrednega študija. Le manjšina članic je poročala, da v okviru vseživljenjskega učenja izvajajo programe za strokovno izpopolnjevanje (predvsem lastnih) diplomantov. Nihče od anketiranih pa ni v kontekstu vseživljenjskega učenja omenil ciljev, kot so alternativne in prožne študijske poti, ECTS, priznavanje in potrjevanje izkustvenega, neformalnega učenja, iz dela izhajajočega učenja itd.

Kljub temu, da rezultati raziskav kažejo na precejšen razkorak med retoriko in dejansko implementacijo vseživljenjskega učenja, pa na mnogih evropskih univerzah $v$ študijske programe vključujejo različne pilotne projekte, eksperimente in nove modele vseživljenjskega učenja. Tako npr. v Veliki Britaniji in Franciji razvijajo postopke za priznavanje in akreditacijo učenja, $k i$ izhaja iz dela, v Nemčiji univerze ponujajo stevilne specializirane programe za starejse državljane, na Švedskem in Norveškem si prizadevajo vzpostaviti kvotni sistem za starejše študente itd.

Kljub nenehnemu skepticizmu akademskega osebja postaja vseživljenjsko učenje sestavni del prizadevanj mnogih univerz, ki se zavzemajo za povečanje in izboljšanje svojih stikov z okoljem in šrjenje sodelovanja z različnimi partnerji. Pri tem se je potrebno vsekakor zavedati, da je uveljavljanje vseživljenjskega učenja bolj odgo- 
vornost vlad kot univerz, ki imajo pri tem pomembno, vendar omejeno vlogo. Uspešno uveljavljanje vseživljenjskega učenja je v pristojnosti javnega sektorja, ki naj zagotovi ustrezne temelje izobraževanja in učenja, dostopnega šrokim krogom odrasle populacije. Čeprav je za učinkovito politiko vseživljenjskega učenja odločilna finančna podpora, lahko opazimo, da v večini držav glavno oviro "vseživljenjskega učenja za vse" predstavlja razkorak med razpoložljivimi javnimi sredstvi, načini financiranja in obsežnostjo zastavljenih ciljev. Toda tudi če država zagotovi svojim državljanom in državljankam enake možnosti učenja, ni dovolj, da to nalogo prepusti univerzam. Pri tem so nujna združena prizadevanja različnih javnih sektorjev, kot so izobraževanje, zaposlovanje, socialno skrbstvo in kultura, ki pogosto delujejo neodvisno eden od drugega. $V$ takšno sodelovanje je potrebno pritegniti tudi zasebni in prostovoljni sektor. Nove oblike partnerstva in sodelovanja so torej nujne, če želimo povečati možnosti učenja za vse skupine prebivalstva. V tem partnerstvu je potrebno ohraniti posebne značilnosti univerze in drugih visokošolskih. institucij, toda le kot enakorrednih, ne pa kot najpomembnejsih partnerjev med mnogimi drugimi organizacijami v "učeči se družbi".

Prof. dr. Sonja Kump

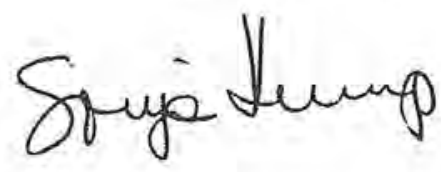

